\title{
МАТВЕЙ НИКОЛАЕВИЧ ЕРШОВ: ВОЗВРАЩЕНИЕ ФИЛОСОФА
}

DOI dx.doi.org/10.24866/1997-2857/2020-4/125-129

\author{
«Я ВЫЕЗЖАЮ ... К СЕБЕ НА РОДИНУ В СССР»: \\ ПИСЬМА ПРОФЕССОРА М.Н. ЕРШОВА \\ АКАДЕМИКУ В.М. АЛЕКСЕЕВУ (1935 г.)
}

\author{
Подготовка к публикации и комментарии О.П. Еланцевой и П.А. Щербина*
}

Китайский период жизни и деятельности Матвея Николаевича Ершова является малоизученным в российской историографии. Остается открытым вопрос о том, чем была наполнена жизнь М.Н. Ершова после 1922/1923 учебного года, проведенного в Пекинском государственном университете, до устройства в 1926 г. на доцентскую должность Юридического факультета в Харбине. Причем обращает на себя внимание определенное «понижение» в должности, т.к. во Владивостоке Ершов находился на профессорской позиции. Этот эпизод требует отдельного исследования и, как представляется, может быть интерпретирован только в совокупности с изучением особенностей жизненного мира интеллектуального эмигрантского сообщества и системы взаимоотношений в нем.

Дальнейшая судьба Матвея Николаевича также скрыта завесой неизвестности, что находит отражение в очень кратких утверждениях исследователей о заключительном этапе его жизни, часто противоречащих друг другу. Печально, но в современных публикациях о М.Н. Ершове присутствуют ошибочные, многократно повторяемые утверждения. Приведем только один пример. По мнению А.В. Костомясовой [4, с. 296] и В.П. Пономаревой [7, с. 213; 8, с. 458 и др.], М.Н. Ершов проработал в Китае до 1937 г., до закрытия Юридического факультета, а затем, одновременно с Н.В. Устряловым покинул его. Здесь обращает на себя внимание следующее противоречие: в письмах Г.Н. Дикому Н.В. Устрялов называет дату своего отъезда в СССР - 19 мая 1935 г. [6].

Полагаем, что публикуемые ниже материалы будут способствовать устранению данной лакуны и дадут новый вектор биографическому поиску. Предлагаемые вниманию читателей документы были выявлены в Санкт-Петербургском филиале Архива Российской академии наук (СФА РАН), в фонде известного востоковеда-китаиста Василия Михайловича Алексеева (ф. 820). Это письма М.Н. Ершова В.М. Алексееву. И в обоих автор упоминает о «любезных письмах», получаемых от академика в 1931 г. и в 1932 г. (СФА РАН. Ф. 820. ОП. 3. Д. 347. Л. 3об.). Матвей Николаевич особо подчеркивает: «За последние четыре года я посылал Вам из Харбина мои печатные работы; Вы всякий раз любезно извещали меня о получении их» (СФА РАН. Ф. 820. Оп. 3. Д. 347. Л. 4об.). Таким образом, становится ясно, что приводимые письменные свидетельства являются лишь малой толикой из эпистолярного диалога В.М. Алексеева и М.Н. Ершова. Вполне возможно, что дальнейшие поиски в данном направлении дадут положительные результаты.

С большой долей вероятности можно предположить, что инициатива рассматриваемого нами заочного (письменного) общения принад-

* ЕЛАНЦЕВА Ольга Павловна, доктор исторических наук, профессор Департамента истории и археологии Школы искусств и гуманитарных наук Дальневосточного федерального университета.

E-mail: elantseva.op@dvfu.ru

ЩЕРБИНА Полина Анатольевна, кандидат исторических наук, доцент Департамента истории и археологии Школы искусств и гуманитарных наук Дальневосточного федерального университета.

E-mail: scherbina.pa@dvfu.ru

(C) Еланцева О.П., Щербина П.А., 2020 
лежит В.М. Алексееву. В свое время он трудился в Публичной библиотеке Ленинграда ${ }^{1}$, состоял внештатно в востоковедных библиотеках разных учебных и научных учреждений российской столицы. Постепенно существенным направлением его деятельности стало планомерное систематическое пополнение китаеведческих книжных фондов, для чего В.М. Алексееву было разрешено использовать ресурсы Бюро по книгообмену с зарубежными странами [2]. С этим обстоятельством связана устанавливаемая им широкая переписка с коллегами-учеными в Китае, преподавателями учебных заведений, служащими учреждений и предприятий этой страны. За границу отправлялись книги, учебники, учебные пособия, программы, которые просили адресаты, а взамен приходили новейшие издания, позволявшие быть в курсе развития науки, культуры, образования, экономики Китая.

Письма М.Н. Ершова академику Алексееву, написанные черными чернилами и торопливым почерком, появились в интервале пяти месяцев: первое из Харбина, датировано 18 мая 1935 г., другое - из Ташкента. Оно имеет помету: 18 октября 1935 г. Из их содержания можно увидеть главные побудительные мотивы обращения М.Н. Ершова к В.М. Алексееву. В письме из Харбина, накануне отъезда в СССР Матвея Николаевича очень волновали вопросы его будущего трудоустройства. Он надеялся получить от своего адресата полезный совет, возможное содействие по применению своих сил и знаний, как вариант - в вузах или научно-исследовательских институтах Ленинграда, но уже не по философии, а по востоковедению. Акценты сместились! Совершенно неслучайно здесь присутствует перечисление основных мест работы Ершова и читаемых им учебных курсов. Оно же говорит о том, как нелегко доставался хлеб насущный в Китае 2 . Можно предположить, что

${ }^{1}$ В настоящее время это Российская национальная библиотека (г. Санкт-Петербург).

2 Подобную информацию доносит до нас послужной список М.Н. Ершова - сотрудника Управления КВЖД. Например, 1 сентября 1931 г. он был зачислен на должность преподавателя курсов китайского языка КВЖД по вольному найму, а в мае 1934 г. был уволен с рядом своих коллег с оскорбительной формулировкой «за минованием надобности». Добавим, что в 1931 г. Ершову, как и другим работникам КВЖД, значительно снизили заработную плату. С марта 1932 г. он выполняет труднейшую работу переводчика, а с июля 1933 г. - драгомана европей- письмо из Ташкента преследует задачу сохранить контакты с известным востоковедом. Это выражалось в желании М.Н. Ершова получить авторитетный отзыв на свою только что опубликованную монографию «Восток и Запад» [3].

В личном деле бывшего работника КВЖД Матвея Николаевича Ершова ${ }^{3}$ в Российском государственном историческом архиве в фонде Правления Китайско-Восточной железной дороги сохранилась доверенность М.Н. Ершова Генеральному Консулу СССР в Харбине. Доверенность была заполнена М.Н. Ершовым 20 мая 1936 г. и заверена нотариусом Н.С. Кутузовой в Ташкенте 21 мая 1936 г. [Российский государственный исторический архив, далее - РГИА. Ф. 323. Оп. 9. Д. 1681. Л. 3). Известно, что 23 марта 1935 г. было подписано Соглашение между СССР и Японией о передаче прав на Китайско-Восточную железную дорогу правительству Маньчжоу-го. Советские граждане, трудившиеся на КВЖД, увольнялись от службы за штат. Они должны были получить единовременную выплату и в течение трех месяцев выехать в СССР [5]. Только до начала августа 1935 г. таковыми стали 6028 бывших служащих КВЖД и 14 607 членов их семей [1, с. 104]. Им полагалось получить окончательный расчет за работу на КВЖД в соответствии с вполне определенными обязательствами и договоренностями той и другой стороны. Вернувшимся в СССР харбинцам предстояло действовать через своего посредника - Генерального Консула СССР в Харбине. Интересно, что уже в июне 1935 г. М.Н. Ершов обратился в Генконсульство с просьбой из сумм, причитавшихся ему к выплате от бывшей КВЖД в 1936 г. и в 1937 г., перевести на постройку самолетов 80 гоби (местные денежные единицы). Просьба была исполнена (РГИА. Ф. 323. Оп. 9. Д. 1681. Л. 8. 10, 12).

Таким образом, публикуемые нами письма позволяют утверждать, что М.Н. Ершов находился в Китае до лета 1935 г. и выехал из Харбина в Советский Союз 30 июня 1935 г. Из документов следует, что М.Н. Ершов был направлен на работу в Ташкент и по крайней мере до середины 1936 г. проживал в этом городе.

В заключение еще раз подчеркнем: мы пока очень мало знаем о жизни Матвея Николаеви-

ских языков экономико-технической части и одновременно ведет занятия в учебных заведениях Харбина (РГИА. Ф. 323. Оп. 9. Д. 1691. Л. 1, 1об.).

3 Заголовок дела содержит уточнение: «работника КВЖД, выехавшего в Советский Союз». 
ча Ершова в Китае в 1920-е - 1930-е гг., о его возвращении в Советский Союз. Надеемся, что серия публикаций материалов о его жизни, предпринятая нами в течение 2020 г., внесла свой небольшой вклад как в расширение наших представлений о сложном периоде социальных потрясений в России и вызванном ими трансфере людей и смыслов, так и в дополнение и уточнение биографии М.Н. Ершова, став частью усилий по «возвращению» философа на Родину.

\section{СПИСОК ЛИТЕРАТУРЫ}

1. Аблажей Н.Н. С востока на восток. Российская эмиграция в Китае. Новосибирск: Издво СО РАН, 2007.

2. Алексеев Василий Михайлович // Российская национальная библиотека [Электронный ресурс]. - Режим доступа: http://nlr.ru/nlr history/persons/info.php?id=6

3. Ершов М.Н. Восток и Запад прежде и теперь. Основные предпосылки проблемы «Восток и Запад» в историческом освещении. Харбин: Наука, 1935.

4. Костомясова А.В. Матвей Николаевич Ершов // Вече. Журнал русской философии и культуры. 2007. Вып. 18. С. 289-296.

5. Кротова М.В. К вопросу о продаже КВЖД СССР Маньчжоу-го в 1935 г. // Социальные и гуманитарные науки на Дальнем Востоке. 2014. № 1. С. 105-111.

6. «Под диктатурой иррациональных факторов». Письма Н.В. Устрялова Г.Н. Дикому из Харбина. 1930-1935 гг. [Электронный ресурс]. - Режим доступа: http://magister.msk.ru/ library/philos/ustryalov/ustry011.htm

7. Пономарева В.П. Правовое наследие юридического факультета в городе Харбине. 19201937 // Вестник Брянского государственного университета. 2014. № 2. С. 209-214.

8. Пономарева В.П. Сохранение традиций русского высшего юридического образования в Китае: юридический факультет в Харбине (1920-1937) // Россия и Китай: история и перспективы сотрудничества: материалы VI международной научно-практической конференции. Благовещенск, 2016. С. 455-460.

\section{REFERENCES}

1. Ablazhei, N.N., 2007. S vostoka na vostok. Rossiiskaya emigratsiya $\mathrm{v}$ Kitae [From east to east. Russian emigration to China]. Novosibirsk: Izd-vo SO RAN. (in Russ.)

2. Alekseev Vasilii Mikhailovich [Alekseev Vasily Mikhailovich]. URL: http://nlr.ru/nlr history/persons/info.php?id=6 (in Russ.)

3. Ershov, M.N., 1935. Vostok i Zapad prezhde i teper'. Osnovnye predposylki problemy «Vostok i Zapad»v istoricheskom osveshchenii [East and West past and present. The main premises of the «East and West» problem in retrospect]. Harbin: Nauka. (in Russ.)

4. Kostomyasova, A.V., 2007. Matvei Nikolaevich Ershov [Matvey Nikolaevich Ershov], Veche. Zhurnal russkoi filosofii i kul'tury, no. 18, pp. 289-296. (in Russ.)

5. Krotova, M.V., 2014. K voprosu o prodazhe KVZhD SSSR Man'chzhou-go v 1935 g. [The issue of sale of Chinese Eastern Railway in 1935], Sotsial'nye i gumanitarnye nauki na Dal'nem Vostoke, no. 1, pp. 105-111. (in Russ.)

6. «Pod diktaturoi irratsional'nykh faktorov». Pis'ma N.V. Ustryalova G.N. Dikomu iz Kharbina. 1930-1935 gg. [«Under the dictatorship of irrational factors». Letters of N.V. Ustryalov to G.N. Dikii from Harbin, 1930-1935]. URL: http:// magister.msk.ru/library/philos/ustryalov/ustry011. htm (in Russ.)

7. Ponomareva, V.P., 2014. Pravovoe nasledie yuridicheskogo fakul'teta $\mathrm{V}$ gorode Kharbine. 1920-1937 [Legal heritage of the faculty of law in Harbin, 1920-1937], Vestnik Bryanskogo gosudarstvennogo universiteta, no. 2, pp. 209214. (in Russ.)

8. Ponomareva, V.P., 2016. Sokhranenie traditsii russkogo vysshego yuridicheskogo obrazovaniya V Kitae: yuridicheskii fakul'tet $\mathrm{V}$ Kharbine (1920-1937) [Preserving the traditions of Russian higher legal education in China: the faculty of law in Harbin, 1920-1937]. In: Rossiya i Kitai: istoriya i perspektivy sotrudnichestva: materialy VI mezhdunarodnoi nauchno-prakticheskoi konferentsii. Blagoveshchensk, 2016, pp. 455460. (in Russ.)

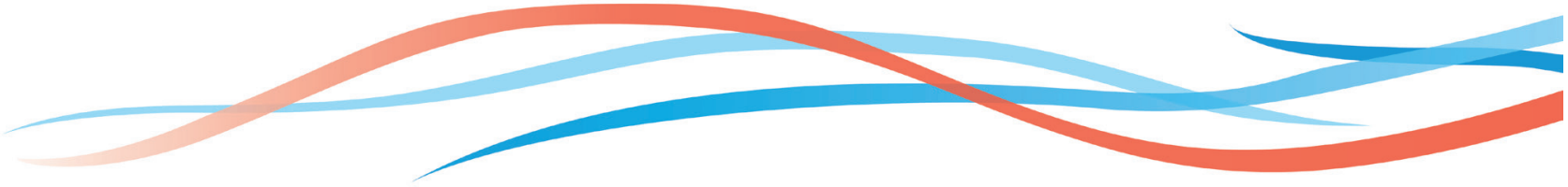


Документ 1

Харбин, Судная ул., д. № 15 , кв. 12

V. 18.1935.

Глубокоуважаемый Василий Михайлович,

неделю тому назад я послал Вам заказною бандеролью свою книжку «Восток и Запад», но не успел написать письма. Между тем, я уже давно собирался написать Вам, и только желание скорее закончить и напечатать свой «Восток и Запад» не давало мне досуга, необходимого для писания писем. Я именно хотел обратиться к Вам за советом и, если возможно, за содействием по вопросу о возможном применении моих знаний и сил в СССР. Как советский служащий ${ }^{4}$ КВжд (за последние три года состоял переводчиком европейских яз[ыков] в технической части Службы Переводов Управления КВжд; кроме того, читал лекции по Истории философии права (Истории политических учений) на Юридическом Факультете, читал Экономику Китая на транспортно-экономическом факультете Харбинского Политехнического Института, преподавал Историю и Экономику Китая на Курсах китайского яз[ыка] КВжд и в Транспортно-индустриальном Техникуме КВжд), я выезжаю приблизительно 20-25 июня или несколько позже к себе на родину в СССР.

Был бы оч[ень] Вам признателен, если Вы, в ответ на это письмо, информировали бы меня относительно научно-исследовательских институтов и вузов Ленинграда и положения в них востоковедения, а также истории колониальных стран и народов. При этом, конечно, мне очень хотелось бы слышать Ваше компетентное мнение о моих печатных работах по востоковедению.

Извините, пожалуйста, что, не будучи лично знаком с Вами, обращаюсь к Вам с вопросами личного характера. Те любезные письма, которые я получил от Вас в 1931-[19]32 гг. дают для меня в этом отношении некоторые основания. Извиняюсь, что давно не писал Вам, так как имел большую нагрузку в смысле работы.

Шлю Вам свой искренний привет.

С почтением и уважением

М. Ершов

СФА РАН. Ф. 820. Оп. 3. Д. 347. Л. 3-3об.

\footnotetext{
${ }^{4}$ Матвей Николаевич Ершов являлся гражданином СССР. Это подтверждал паспорт за № 20050, выданный ему Генеральным Консульством СССР в Харбине от 12 апреля 1929 г. (РГИА. Ф. 323. Оп. 9. Д. 1671. Л. 1, 1об.).
} 
Документ 2

Проф[ессор]

Матвей Николаевич Ершов

Ташкент. Кашгарская ул.,

д. № 16 , кв. 2

18.X.1935

Глубокоуважаемый Василий Михайлович,

вот уже три месяца, как я живу в Ташкенте, куда прибыл в порядке эвакуации советских служащих КВжд: здесь в настоящее время состою профессором истории зависимых и колониальных стран в двух местных педвузах; причем, один из них только что открылся осенью этого года ${ }^{5}$. Все время собирался написать Вам. Но, как Вы, наверное, знаете, на новом месте сначала следует «обжиться».

Пред выездом из Харбина я в спешном порядке напечатал книжку: «Восток и Запад. Основные предпосылки проблемы Восток и Запад в историческом освещении». Числа 11 мая я послал Вам ее заказною бандеролью, а числа 18 - заказное письмо. Но не знаю до сих пор, получили ли Вы то и другое: из Харбина я выехал в СССР 30 июня. И возможно, что Вы написали мне по получении книжки, но письмо Ваше уже не застало меня в Харбине. А может быть Выне получили ни книжки, ни письма моего. В таком случае я охотно послал бы Вам мой «Восток и Запад» отсюда, из Ташкента: у меня имеется ограниченное количество экземпляров.

За последние четыре года я посылал Вам из Харбина мои небольшие печатные работы; Вы всякий раз любезно извещали меня о получении их. И в данном случае, мне, конечно, хотелось бы иметь Ваш авторитетный отзыв о моем «Востоке и Западе».

Для научной работы в Ташкенте имеются две библиотеки: фундаментальная библиотека САГУ и Госуд[арственная] Публичная библиотека. Пока пользуюсь, главным образом, первою, так как из нее можно брать книги на дом.

Буду оч[ень] рад получить от Вас письмо.

С искренним уважением и приветом.

Ваш М. Ершов

СФА РАН. Ф. 820. Оп. 3. Д. 347. Л. 4-4об.

${ }^{5}$ В Ташкенте работал Среднеазиатский государственный университет (САГУ). 14 сентября 1935 г. на базе педагогического факультета САГУ был открыт Ташкентский государственный педагогический институт. 